\title{
The Effectiveness of Learning the Indonesian Language Using Spada in the Pandemic Time Covid-19 at Prima Indonesia University Medan
}

\author{
Nova Mawar Hutabarat ${ }^{\mathbf{1}}$, Sadieli Telaumbanua ${ }^{2}$ \\ ${ }^{1,2}$ Universitas Prima Indonesia \\ novamawar123@gmail.com
}

\begin{abstract}
This study aims to find out The Effectiveness of Learning the Indonesian Language Using Spada in the Pandemic Time Covid19 at Prima Indonesia University Medan. This research is a descriptive qualitative and quantitative descriptive study using online questionnaires and interviews, this is based on the formulation of research problems that require researchers to explore in order to understand and explain what is being studied through an intensive relationship with data sources. Based on the results of questionnaires and interviews and in accordance with the problems, several conclusions can be drawn, namely: 1.Learning Indonesian using SPADA during the Covid-19 pandemic was effective, namely, both from the results of questionnaires and interviews with lecturers and students. 2. The process of learning Indonesian using SPADA starting from planning, implementation and assessment is carried out effectively. 3. The opinion of lecturers and students to make Indonesian language learning more effective using SPADA is to add other features such as Zoom Meeting or Google Classroom.
\end{abstract}

Keywords

effectiveness;

learning; pandemic

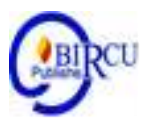

\section{Introduction}

Education is one way to produce quality Human Resources (HR) with experience changes in knowledge, skills and attitudes. These changes can be a capital to improve selfcompetence in facing the era of globalization that always undergoes the change (Sitorus et al, 2019). Online learning or distance learning itself aims to meet educational standards through the use of Information Technology using computers or smartphones that are connected to each other between students and lecturers. Through the use of these technologies, learning can still be carried out properly. With this information technology, it is hoped that learning can run well considering that the majority of Indonesians currently use the internet, as explained in the We Are Social research, "Digital Reports 2020" which was released at the end of January 2020 which stated that nearly $64 \%$ of Indonesia's population was connected with an internet network.

There are quite a lot of choices for online learning applications that can be applied in the world of education. One of the free and familiar applications implemented is the Google Classroom application. Teachers, lecturers, tutors and instructors in general can open classes and invite students to the class. Online learning in the application can take place with various materials and assignments given by teachers to students. Teachers can also provide grades related to assignments that are collected neatly and well archived. The online learning that is applied allows teachers and students to carry out learning without going through face-to-face in the classroom by providing learning material (in the form of 
power point slides, e-books, learning videos etc., assignments (independent or group), as well as assessment. (Silalahi et al, 2020)

Learning Indonesian Language is one of the lessons that must be implemented in education in Indonesia. The 2013 curriculum places Indonesian as an advocate for other subjects and therefore must be ahead of all other subjects. Learning Indonesian has four language skills that students must have, namely listening, speaking, reading and writing skills (Dalman, 2012: 3). Indonesian is one of the subjects taught from basic education to higher education. Indonesian is one of the sciences that has an important role in human life and in mastering science and technology. As Indonesians, it is important for us to learn and understand Indonesian properly and correctly (Afifah, 2012: 2).

UNPRI (Prima Indonesia University) uses an alternative SPADA (Online Learning System) with SIA (Academic Information System) in Indonesian language learning as a learning medium which is an innovation from UNPRI itself that can be used in the learning process, not only in delivering learning materials, but also changes in the abilities of various competences of students. SPADA is a learning system that allows teaching materials to be delivered to students using internet media or other computer network media that can be accessed anytime and anywhere in the hope that the learning process can take place well.

\section{Review of Literature}

\subsection{Definition of Effective}

Effectiveness comes from the word effective, which means that it has an effect or effect. While effectiveness means the success of a particular action. In learning activities an action is the use of an approach, method or strategy by the lecturer. Thus, the more maximum the results are achieved, the more effective it is. is also a learning activity. In the Big Indonesian Dictionary (2007: 284) the word effective means there is an effect, influence or effect, besides that effective can also be interpreted as being able to bring results, or be effective.

The factors that affect the effectiveness of learning are the ability of the lecturer to use the learning method, where the learning method is influenced by the objective factors, the student, the situation, the facilities, and the teacher himself. According to Sadiman in Trianto (2009: 20) the effectiveness of learning is the useful results obtained after the implementation of teaching and learning activities.

. Effectiveness is effectiveness, effectiveness, conformity in an activity or a situation that indicates the extent to which the plan can be achieved. The more plans that can be achieved, the more effective these activities are, so that the word effectiveness can also be interpreted as the level of success that can be achieved from a certain method or effort in accordance with the objectives to be achieved. To find out the effectiveness of teaching can be done by giving a test, because with test results can be used to evaluate various aspects of the teaching process.

\subsection{Learning Effectiveness}

The level of achievement is a measure that must be achieved by students in learning. The achievement of learning objectives can be in the form of increasing knowledge, skills and skills. Knowing the effectiveness of a lesson is important because it will provide an overview of the extent to which learning can achieve its goals. Therefore, so that students can achieve learning objectives, innovative learning activities are needed that facilitate students in learning so that students understand the concepts presented by the lecturers. 
Effective learning is not only seen from the results but also through the learning process. This was expressed by Hamruni (2012: 23) through the principles of effective learning including goal orientation, activity, individuality, and integrity. There are two important definitions of effective learning, namely, the occurrence of learning in students and what the teacher does to teach students (Hamzah B. Uno and Nurdin Mohamad, 2014: 174).

The effectiveness of the learning process can be seen from several existing indicators. Attitudes from students, student and lecturer activities that occur, and learning outcomes can be one of the things that are used as indicators of learning effectiveness (In'am, 2012). An explanation of the meaning of effectiveness can represent the meaning of learning effectiveness, namely the process of learning activities where learning tools such as models, methods, techniques and others are able to help students or lecturers to achieve the goals of learning (Bash, 2015).

The suitability of the activities in carrying out the learning process and objectives shows the effectiveness of the learning process. The implementation of all assignments with the estimated time available, the achievement of learning objectives, the participation shown by students and lecturers is also a focus for seeing the effectiveness of learning (Setiyaningrum, 2015). So far, the learning process still focuses on the lecturers. Lecturers are the focus of all learning that is taking place. Such a focus makes students lazy to follow the learning. According to Supardi (2013: 164-165) effective learning is a combination structured including humane, material, facilities, equipment and procedures directed to change student behavior in a positive and better direction according to the potential and differences that students have to achieve learning goals has been established.

Eka Nur Anisa (2013: 5) states that the effectiveness of learning is the relationship between the goals and outcomes of learning. The completeness of the learning results shows the achievement of the learning objectives that have been planned so that learning is said to be effective. In addition, it is effective not only oriented to results but also the processes that exist in achieving goals. So it can be concluded that effective learning is learning that is oriented towards learning programs with regard to efforts to influence, give effect, which can bring results in accordance with the objectives and processes that are in the learning itself.

The factors that affect the effectiveness of learning are the ability of the teacher to use learning methods, where the learning method is influenced by the objective factors, students, situations, facilities, and the teacher himself. According to Sadiman in Trianto (2009: 20) the effectiveness of learning is the useful results obtained after the implementation of teaching and learning activities. The characteristics of the effectiveness of the learning program are the success in delivering students to achieve predetermined instructional goals, providing an attractive learning experience, involving students actively so as to support the achievement of instructional goals and having the means that support the teaching and learning process.

To achieve an effective and efficient learning concept, it is necessary to have a reciprocal relationship between students and lecturers to achieve a common goal, besides that it must also be adapted to environmental conditions, facilities and infrastructure, as well as the learning media needed to help achieve all aspects of student development. The effectiveness of learning is a measure of the success of the interaction process in educational situations to achieve learning objectives. Judging from the activities during learning, response and understanding of concepts. So, the effectiveness of learning is a process and certain efforts to achieve goals in learning or achieve the desired level of success. 


\subsection{Understanding Indonesian Language Learning}

Learning is a process to help students learn well. According to Abidin (2015: 3) Learning is a series of processes carried out by teachers so that students learn. From the student's point of view, learning is a process that contains a set of activities carried out by students to achieve learning goals. Based on these two definitions, basically learning is a series of activities carried out by students in order to achieve certain learning outcomes in the guidance and direction and motivation of a lecturer.

In line with Kristiantari's (2010: 18) opinion which states that learning is the process of presenting information and activities designed by the teacher to help facilitate students in achieving the expected learning goals. The competency standard for Indonesian language subjects is the minimum ability qualification of students that describes the mastery of knowledge, language skills, and a positive attitude towards Indonesian language and literature. Competency standards in Indonesian subjects are rooted in the essence of language learning, namely learning language is learning to communicate, and learning literature is learning to respect human work.

There are several meanings of language learning. Harimurti defines language learning as a process of mastering one's own language or another language by a human being. This endeavor activity will result in students being able to learn something in an effective and efficient way. Efforts can be made in the form of analyzing the objectives and characteristics of studies and students, analyzing learning resources, establishing organizational strategies, learning content, determining learning delivery strategies, establishing learning management strategies, and establishing procedures for measuring learning outcomes. Therefore, every teacher must have the skills in choosing a learning strategy for each type of learning activity. Thus, it is expected that the achievement of learning objectives can be fulfilled.

Reading is essentially a complex thing that involves many things, not only reciting the writing, but also involving visual, thinking, psycholinguistic, and metacognitive activities. As a visual process, reading is a process of translating written symbols (letters) into spoken words. As a thought process, reading includes word recognition activities, literal comprehension, interpretation, critical reading, and creative understanding. (Rahim, 2008: 2).

The principle of the reading skills learning model is reading for pleasure, which means reading for pleasure and reading for information, namely reading to obtain information. From some of the things above about reading, it can be formulated to understand the content of what is written, and to spell or pronounce what is written. In reading there are several stages, including:

\section{Beginning Reading}

This stage is the initial stage in reading reading. In this case, starting reading is mechanical which can be considered to be in a lower order. Beginning reading is an initial skill that must be learned or mastered by readers. Beginning reading is the initial level so that people can read (Dalman, 2013: 85).

Preliminary reading is the initial stage of learning to read so that they can move up to the level of reading comprehension. When reading the beginning students are introduced to words or sentences that they often hear and often repeat and spell letters into words and sentences. Reading the beginning is a complex activity that includes the ability in question is the ability or ability of students to read with clear pronunciation, clear intonation and correctness. Teaching of early reading is emphasized more on developing basic reading skills. Students are required to be able to voice letters, syllables, and sentences that are 
presented in the form of written into oral form (Arijani, 2013). It can be concluded that reading the beginning of the early stages that will determine the achievement results enter the advanced reading stage. If you can master reading the beginning, it will be easy to enter the next stage. Reading the beginning of the student is able to voice the symbol of the letter being read.

\section{Comprehensive Reading or Advanced Reading}

Reading comprehension is a reading skill that is in a higher order. Reading comprehension is cognitive reading (reading to understand). In reading comprehension, readers are required to be able to understand the content of the reading. Therefore, after reading the text, the reader can convey the results of his reading comprehension by making a summary of the reading content using his own language and conveying both orally and in writing (Dalman, 2013: 87). Basically reading comprehension is a continuation of reading the beginning. If a reader has gone through the pre-reading stage, he has the right to enter into the reading comprehension stage or further reading. Here a reader is no longer required to pronounce the letters correctly and assemble each sound of the language into the form of words, phrases and sentences. However, here he is required to understand the content of the reading he is reading.

Listening and reading are closely related because both are means of receiving information in communication activities; the difference lies in the type of communication: listening is related to oral communication, while reading is related to written communication. In terms of objectives, both contain similarities, namely obtaining information, capturing content or messages, and understanding the meaning of communication (Tarigan, 2008: 30-31). Listening is a process of listening to oral symbols with attentiveness, understanding, appreciation, and interpretation to obtain information, capture content or messages, and understand the meaning of communication that has been conveyed by the speaker through speech or spoken language. So it can be concluded that listening skills are a process of absorbing scientific information from various sources, listening to the sense of hearing is the main asset for obtaining information, and when obtaining this information it is the cognitive attitude that will discover and understand various sciences that can be applied in everyday life day.

\subsection{Indonesian Language Learning Objectives}

The purpose of a lesson becomes the basis for reference in learning activities. Likewise, the purpose of learning in Indonesian, lecturers provide learning in the hope that students can achieve the general goals of learning Indonesian.

\subsection{SPADA (Online Learning System)}

SPADA stands for Online Learning System. SPADA Indonesia is a program of the Directorate General of Learning and Student Affairs of the Ministry of Research, Technology and Higher Education (Kemenristek Dikti) which aims to increase equitable access to quality learning in Higher Education. Online Learning is an extension of learning in a network (online) with learning patterns through the help of internet networks so that there will be interactions in teaching and learning activities between students and lecturers. This online learning is also carried out using information technology. According to Dabbaghd and Ritland (in Arnesidan Hamid, 2015) online learning is an open and distributed learning system using pedagogical tools (educational aids), which are made possible through the internet and network-based technology to facilitate the formation of learning and knowledge processes through meaningful actions and interactions. 


\subsection{SIA (Academic Information System)}

Academic is a field that studies curriculum or learning in its function to increase knowledge in terms of education / learning that can be managed by a school or educational institution (Catur, 2009). Academic Information System is software used to present information and organize administrative related to academic activities. By using software like this it is expected that academic administration activities can be managed properly and the required information can be obtained easily and quickly (Satoto, 2008).

Academic Information System is a system designed for the purposes of managing academic data with the application of computer technology both hardware and software so that the entire process of academic activities can be managed into useful information in managing college management and making decisions for decision makers or top management. in a college environment.

This system aims to support the implementation of education, so that universities can provide better and more effective information services to their communities, both inside and outside the tertiary institutions via the internet. The various needs in the field of education and the regulations that surround it are so high that academic management in an educational institution becomes a very draining job of time, energy and mind. The benefits of academic information systems are divided into two, namely:

1. Benefits of Academic Information Systems for Higher Education:

a. Facilitate Academic \& Non Academic Data Management Process

b. The Academic Information System is very helpful in managing student grade data, courses, teaching staff / lecturer data and faculty / department administration which are still manual to work with the help of software in order to be able to streamline time and reduce operational costs.

c. Data Integration

d. Considering that in a university there are several applications and systems, data integration is very useful to avoid duplication of data. Integration means that there is a link between one system and another. By using data integration, this means that each individual piece of information can share the same data at the same time.

e. As an Information Center

f. By using the Academic Information System, it will make it easy for students and lecturers to access information anywhere and anytime. Information that can be accessed includes Course Values, GPA and GPA, Class Schedule, Attendance, Student and Lecturer Data, and much more related to academic information.

g. Tool to Record All Campus Activities

h. Apart from being an information center, the Academic Information System can also be used to record all campus activities. Information on the latest campus activities can be updated in the Academic Information System so that students and lecturers who are unable to attend can find out about ongoing activities.

i. Provide Student Development Reports in the Teaching and Learning Process

j. With the campus academic information system, it will be easier to monitor student progress in the teaching and learning process, because attendance data, learning values already exist in the academic information system.

k. Provide Lecturer Development Reports in Teaching and Learning Activities

1. With the academic information system, it can also monitor the development of lecturers in the teaching and learning process.

m. Campus More Up to Date

n. The academic information system provides information needed by the university regarding up to date student academic data at a low cost. 
o. Improve Campus Image

p. Academic information systems can improve the image of a university as a campus that is caring, transparent, and takes one step forward in the field of technology.

q. Comprehensive Report

r. Get comprehensive reports on student academic achievement, tuition payments, and others that are presented in online form via the Web media.

s. Make it easy for Academic Officers

t. Academic information service providers are easier to carry out their duties.

u. Facilitate Reporting to PDPT Dikti

v. Provides convenience in making reports for data reporting (PDPT) to DIKTI in accordance with national standards.

2. as a Guide in Preparing Campus Policies

Academic Information Systems can also function as a support for data analysis in determining Campus decisions

3. Benefits for Students:

a. Make it easy for students to fill in and repair KRS

b. Facilitate and speed up student registration or her-registration and payments

c. Make it easy to get IP data per semester, course schedules, UTS scores, UAS scores, assignment scores, remedials, and the latest information from majors.

d. Students can see their grades through SIAKAD Mobile, making it faster.

e. Students can find out academic information anytime and from anywhere.

Therefore, the academic information system was built to answer directly the problems and needs of higher education institutions for academic management quickly and not tiring.

\section{Research Methods}

The method is one of the ways used to achieve the goal, while research is a container for finding the truth. Through the right method, a researcher is not only able to see facts as reality, but also to predict the possibilities that will occur through facts. The purpose of this research is to find the effectiveness of Indonesian Language Learning Using SPADA which is applied in the Prima Indonesia University Environment.

This research is a descriptive qualitative and quantitative descriptive study using online questionnaires and interviews, this is based on the formulation of research problems that require researchers to explore in order to understand and explain what is being studied through an intensive relationship with data sources.

In this case the researcher uses data in the form of a description of the effectiveness of Indonesian language learning with the SPADA application which is researched through questionnaires and interviews. This is done to collect information from the respondents using a questionnaire as the main method. This study aims to find the effectiveness of Indonesian language learning with SPADA in Universitas Prima Indonesia during the COVID-19 pandemic using SIA. 


\section{Results and Discussion}

\subsection{Learning Indonesian Using SPADA}

The research was conducted by means of interviews and questionnaires using google form which were distributed to lecturers and students to determine the effectiveness of Indonesian language learning using SPADA and from the distribution of these questionnaires it would be known the results of the effectiveness of the learning. The process of teaching activities at UNPRI with SPADA has actually started since 2019 but only for certain subjects, and due to the current pandemic conditions, all course learning is carried out with SPADA including Indonesian Language learning. Indonesian language learning is carried out with SPADA in order to fulfill student learning where Indonesian language courses are compulsory courses taken by UNPRI students.

\subsection{SIAM (Student Academic Information System)}

The Academic Information System at UNPRI is very good and controlled, UNPRI students can access it anywhere by using Andorid or a secure computer with the internet. To be able to log into the SIA, students are given a NIM (Student Identification Number) at the beginning of the lecture, after being given NIM, they will be given the same password as the NIM and students can change it after being given the password. Students studying with SPADA first have to go to their respective SIA to be able to access SPADA and for biased access to these courses Students must get Enrolment Keys from the lecturers who take the courses after the Students can see the learning material and fill in the attendance list.

\subsection{Indonesian Language Learning Process with SPADA}

According to Dabbagh and Ritland (2005: 15) online learning is an open and distributed learning system using pedagogical tools (educational aids), which are made possible through the internet and network-based technology to facilitate the formation of learning and knowledge processes through meaningful actions and interactions.

Indonesian language learning carried out with SPADA has three stages in which the three stages are to fulfill the effectiveness of the learning process, while the stages are carried out as follows:

Spada access can be done by students through the Student Academic Information System (SIAM), which is located on the following page: http://unprimdn.ac.id/login, After logging in Students with ID and password can access SPADA Access it in the same way, namely using ID and password and choosing according to each faculty is an independent registration process carried out by incoming students Course using the Group Enrollment Key, and the Group Enrollment Key can be obtained through the course lecturers respectively.

\subsection{Indonesian Language Learning Planning with SPADA}

\begin{tabular}{|c|c|}
\hline Research question & Answer by the SPADA Coordinator \\
\hline $\begin{array}{l}\text { 1. What were the Considerations for } \\
\text { Indonesian Language Learning } \\
\text { carried out with SPADA during the } \\
\text { Pandemic? }\end{array}$ & $\begin{array}{l}\text { of the Pandemic Situation, but } \\
\text { all, certain courses have } \\
\text { ly been conducted with SPADA }\end{array}$ \\
\hline $\begin{array}{l}\text { 2. How was the First Time Learning } \\
\text { Indonesian } \\
\text { implemented? }\end{array}$ & $\begin{array}{l}\text { It went well, but not at tirst because the } \\
\text { system is new, so there are still a lot of } \\
\text { improvements to be done. }\end{array}$ \\
\hline
\end{tabular}




\begin{tabular}{|l|l|}
\hline $\begin{array}{l}\text { 2. Is there any socialization to lecturers } \\
\text { and students in learning Indonesian } \\
\text { using SPADA? }\end{array}$ & $\begin{array}{l}\text { Yes, where the socialization is carried out } \\
\text { by each faculty }\end{array}$ \\
\hline $\begin{array}{l}\text { 3. Since when was the Indonesian } \\
\text { Language Learning carried out with } \\
\text { SPADA? }\end{array}$ & Since 2019 \\
\hline $\begin{array}{l}\text { 4. Will the Indonesian Language } \\
\text { Learning with SPADA be carried out } \\
\text { continuously? }\end{array}$ & no, but for the assessment will be done with \\
SPADA
\end{tabular}

From the results of the interview above, it can be concluded that the planning of learning Indonesian with SPADA in the Prima Indonesia University environment existed before the pandemic.

\subsection{Implementation of Indonesian Language Learning with SPADA}

\begin{tabular}{|l|l|}
\hline \multicolumn{1}{|c|}{ Research question } & \multicolumn{1}{|c|}{ Answer by the SPADA Coordinator } \\
\hline $\begin{array}{l}\text { 1. What preparations do lecturers and } \\
\text { students do to be able to take part in } \\
\text { Indonesian language learning with } \\
\text { SPADA }\end{array}$ & $\begin{array}{l}\text { Understand using SPADA and make } \\
\text { material into learning into the SPADA, then } \\
\text { make attendance and lecture time according } \\
\text { to the specified time }\end{array}$ \\
\hline $\begin{array}{l}\text { 2. Is Indonesian language learning with } \\
\text { SPADA supported by adequate } \\
\text { facilities and infrastructure? }\end{array}$ & $\begin{array}{l}\text { Yes, because only using Smartphones and } \\
\text { Laptops, you can open it anywhere. }\end{array}$ \\
\hline $\begin{array}{l}\text { 3. Is the material delivered by lecturers } \\
\text { in Indonesian learning with SPADA } \\
\text { according to the needs of students. }\end{array}$ & $\begin{array}{l}\text { It is appropriate, because at the beginning of } \\
\text { the lecture the material entered in SPADA } \\
\text { will be checked by the SPADA Team. }\end{array}$ \\
\hline $\begin{array}{l}\text { 4. Are lecturers able to use the features } \\
\text { available in SPADA in Indonesian } \\
\text { language learning. }\end{array}$ & $\begin{array}{l}\text { There are those who are capable, some are } \\
\text { not, but most of them are capable }\end{array}$ \\
\hline $\begin{array}{l}\text { 5. Do lecturers and students carry out } \\
\text { lectures according to the time } \\
\text { specified in Indonesian language } \\
\text { learning with SPADA. }\end{array}$ & Corresponding, \\
\hline
\end{tabular}

The implementation of learning carried out by SPADA is good, it is as planned. 
4.6 Assessment of Indonesian Language Learning with SPADA

\begin{tabular}{|l|l|}
\hline \multicolumn{1}{|c|}{ Research question } & \multicolumn{1}{|c|}{ Answer by the SPADA Coordinator } \\
\hline $\begin{array}{l}\text { 1. How to conduct an assessment of } \\
\text { Indonesian language learning with } \\
\text { SPADA }\end{array}$ & $\begin{array}{l}\text { Assessment can be done by looking at the } \\
\text { results of the dose questionnaire at the end } \\
\text { of the lesson }\end{array}$ \\
\hline $\begin{array}{l}\text { 2. Changes in What Happens During } \\
\text { Learning Indonesian with SPADA }\end{array}$ & $\begin{array}{l}\text { Social change is the lack of interaction } \\
\text { between lecturers and students }\end{array}$ \\
\hline $\begin{array}{l}\text { 3. Are there any obstacles for lecturers } \\
\text { and students in learning Indonesian } \\
\text { with SPADA }\end{array}$ & $\begin{array}{l}\text { There, sometimes students cannot nail down } \\
\text { the Enrollment Key, and lecturers do not } \\
\text { understand its use }\end{array}$ \\
\hline $\begin{array}{l}\text { 4. What to do To monitor Indonesian } \\
\text { language learning activities with } \\
\text { SPADA }\end{array}$ & $\begin{array}{l}\text { Monitor with the team that has been } \\
\text { determined }\end{array}$ \\
\hline $\begin{array}{l}\text { 5. What is done after an assessment of } \\
\text { Indonesian language learning with } \\
\text { SPADA is carried out? }\end{array}$ & $\begin{array}{l}\text { Performance improvement for both lecturers } \\
\text { and the SPADA system itself }\end{array}$ \\
\hline
\end{tabular}

From an assessment point of view, it can be seen that it is good because there is a team that helps in the learning process.

\subsection{The Effectiveness of Indonesian Language Learning with SPADA}

a. Results of Interviews with Students

\begin{tabular}{|c|c|}
\hline Researcher Questions & Student Answers \\
\hline $\begin{array}{l}\text { 1. Can Learning Indonesian Using } \\
\text { SPADA Be Well Understood? }\end{array}$ & $\begin{array}{l}\text { Yes, the reason is because the material can } \\
\text { be read over and over again and can ask the } \\
\text { lecturers personally }\end{array}$ \\
\hline $\begin{array}{l}\text { 2. How is the level of teaching } \\
\text { lecturers to students in learning } \\
\text { Indonesian using? }\end{array}$ & $\begin{array}{l}\text { Good, because with a pandemic situation so } \\
\text { this is the choice to choose. }\end{array}$ \\
\hline $\begin{array}{l}\text { 3. Is the Lecturer active in learning } \\
\text { Indonesian with SPADA }\end{array}$ & $\begin{array}{l}\text { Yes, because the lecturer can answer } \\
\text { questions well }\end{array}$ \\
\hline $\begin{array}{l}\text { 4. Is the time used by the lecturer in } \\
\text { accordance with the time specified } \\
\text { in Indonesian learning with } \\
\text { SPADA. }\end{array}$ & $\begin{array}{l}\text { Sometimes it is. Sometimes it's not due to } \\
\text { holidays, so you have to change hours }\end{array}$ \\
\hline $\begin{array}{l}\text { 5. Are all Indonesian language } \\
\text { learning subjects effectively carried } \\
\text { out with SPADA? }\end{array}$ & $\begin{array}{l}\text { No, like a scientific essay material, because } \\
\text { there are many discussions, it is better to } \\
\text { immediately practice }\end{array}$ \\
\hline $\begin{array}{l}\text { 6. How Lecturers provide an } \\
\text { assessment of the results of learning } \\
\text { Indonesian Language with SPADA }\end{array}$ & $\begin{array}{l}\text { Lecturers give good grades, scores are given } \\
\text { in uts and in uas }\end{array}$ \\
\hline
\end{tabular}

From the interview above, it can be concluded that learning Indonesian with SPADA during the pandemic is effective and can be understood well.

In this study, students of the Prima Indonesia University in the city of Medan in several study programs. The number of respondents was 250 people. The data on the distribution of respondents are as followsfollowing. 
a. The Indonesian Language Learning Process with SPADA during the Covid-19 Pandemic was very smooth

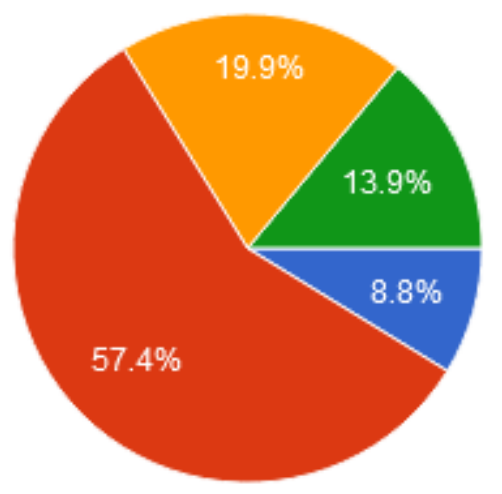

Strongly Agree

Agree

Doubtful

Disagree

Based on the picture above a, it is known that the respondents answered various questions. Figure 1 explains that as many as $57.4 \%$ of students agree with SPADA learning. Students are hesitant about learning SPADA 39.8\%, and there are as many as $13.9 \%$ students who do not agree with SPADA learning. And there were $8.8 \%$ of students who agreed to have learning with SPADA during the Covid-19 pandemic.

b. Is planning for Indonesian language learning during the Covid-19 Pandemic Period with SPADA well socialized?

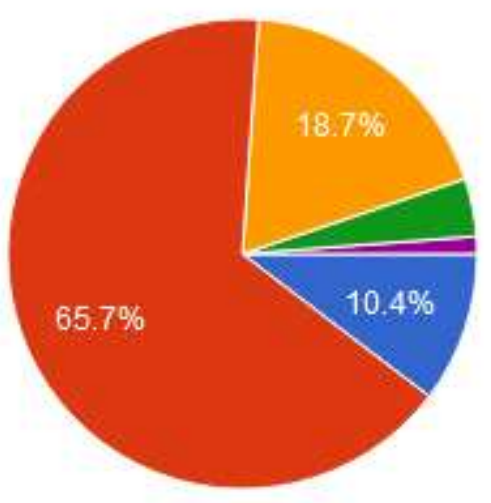

\author{
Strongly Agree \\ Agree \\ Doubtful \\ Disagree \\ Strongly Disagree
}

Furthermore, in figure $b$ there are the results of online questionnaires about whether planning for Indonesian language learning during the Covid-19 pandemic with SPADA is well socialized. Namely the student's answer, there are $65.7 \%$ agree, $18.7 \%$ doubtful, and $10.4 \%$ strongly agree, $4 \%$ students disagree, and $1.2 \%$ strongly disagree. 
c. Was the Implementation of Indonesian Language Learning with SPADA Very Good During the Covid 19 Pandemic?

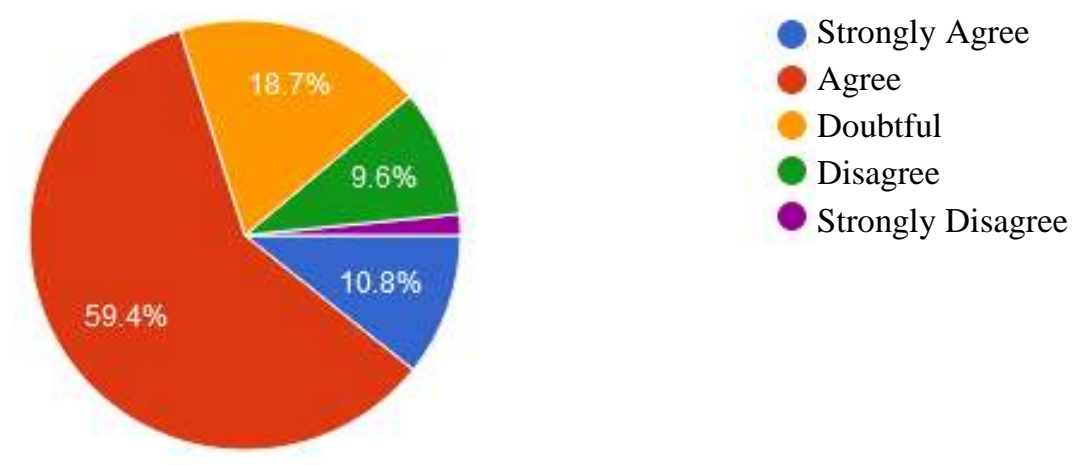

In figure $\mathrm{c}$, it can be seen that the results of online questionnaires about the Implementation of Indonesian Language Learning with SPADA are Very Good During the Covid 19 Pandemic, namely there are students who answer 59.4\% agree, $18.7 \%$ are doubtful, and $10.8 \%$ strongly agree, $9,6 \%$ of students disagreed, and $1.2 \%$ strongly disagreed.

d. Learning Indonesian with SPADA is very easy to access anywhere during the Covid-19 pandemic
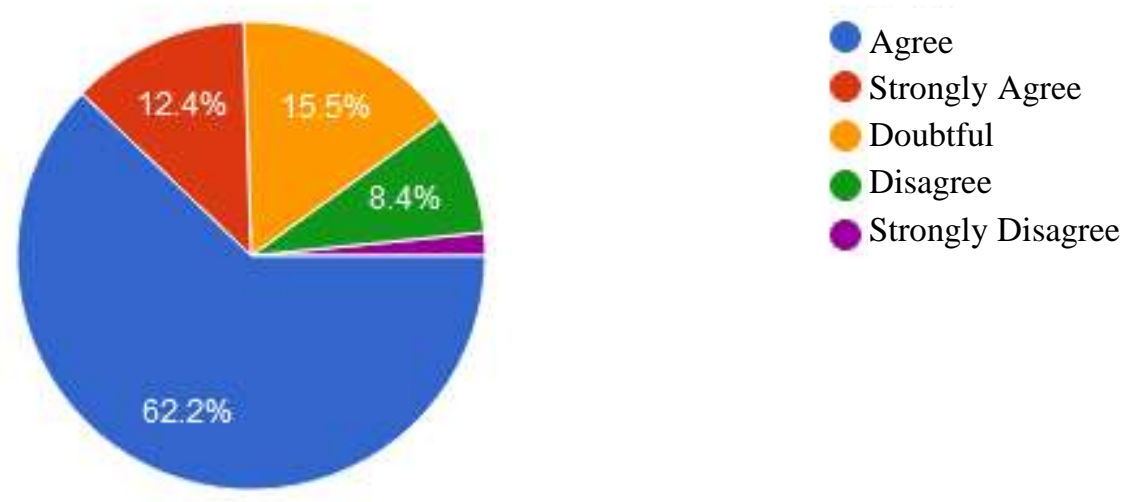

The results of the descriptive study describe students who agree that learning using SPADA is easily accessible anywhere, which is $62.2 \%$, students who are in doubtful are $15.5 \%$, some students answer strongly that learning Indonesian with SPADA can be accessed anywhere easily namely $12.4 \%$, and there were $8.4 \%$ who answered disagree and $1.6 \%$ of students strongly disagreed that learning Indonesian with SPADA could be accessed easily. 
e. Lecturers Able to Use SPADA Well in Learning Indonesian during the Covid-19 Pandemic

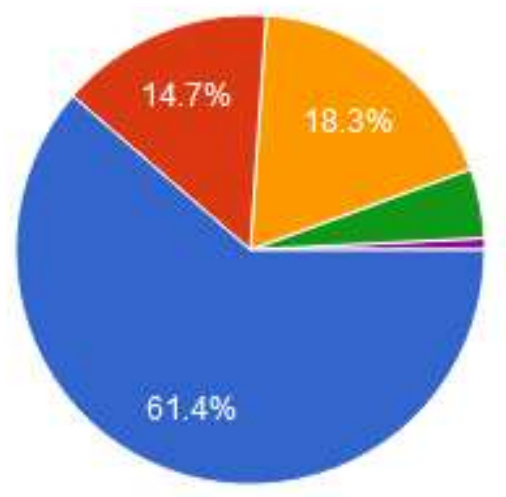

Agree

Strongly Agree

Doubtful

Disagree

Strongly Disagree

In the picture above, it was found that there were $61.4 \%$ of students who said lecturers were able to use SPADA when learning Indonesian, $18.3 \%$ of students answered doubtful, $14.7 \%$ of students answered strongly disagree, $4.8 \%$ of students answered no agree and the last one there is $0.8 \%$ of students answered strongly disagree.

4. 8 Lecturer Interview Results

\begin{tabular}{|l|l|}
\hline Researcher Questions & \multicolumn{1}{|c|}{ Lecturer Answers } \\
\hline $\begin{array}{l}\text { 1. What are the Opinions of Lecturers } \\
\text { learning Indonesian with SPADA } \\
\text { during the Covid-19 Pandemic } \\
\text { Period }\end{array}$ & $\begin{array}{l}\text { Learning Indonesian with SPADA during the } \\
\text { Covid 19 Pandemic, really helped me as a } \\
\text { lecturer. Due to the Covid 19 pandemic, it does } \\
\text { not allow lecturers to come face to face with } \\
\text { students. With SPADA, all learning materials } \\
\text { can be delivered to students. }\end{array}$ \\
\hline $\begin{array}{l}\text { 2. What are the Opinions of Mr / Ms } \\
\text { Lecturers So that Indonesian } \\
\text { Language Learning with SPADA } \\
\text { becomes More Effective during } \\
\text { the Covid-19 Pandemic? }\end{array}$ & $\begin{array}{l}\text { communication between lecturers and students is } \\
\text { more intensive }\end{array}$ \\
\hline $\begin{array}{l}\text { 3. What were the obstacles for Mr / } \\
\text { Indonesian With SPADA during } \\
\text { the Covid-19 Pandemic }\end{array}$ & $\begin{array}{l}\text { During the lecture, I have not encountered any } \\
\text { obstacles that hinder the course of the lecture } \\
\text { process. It's just that, there are small obstacles } \\
\text { such as students forgetting to fill attendance or } \\
\text { not being able to fill attendance because they are } \\
\text { late entering. }\end{array}$ \\
\hline $\begin{array}{l}\text { 4. What According to Mr / Ms } \\
\text { Lecturer the Assessment of } \\
\text { Indonesian Language Learning } \\
\text { with SPADA during the Covid-19 } \\
\text { Pandemic }\end{array}$ & $\begin{array}{l}\text { Of course everything has advantages and } \\
\text { disadvantages. The use of Spada in Indonesian } \\
\text { language learning is still relatively new and } \\
\text { requires habituation. In this respect, my } \\
\text { assessment of this kind of learning falls into the } \\
\text { very good category in its current state. }\end{array}$ \\
\hline $\begin{array}{l}\text { 5. What According to Mr / Ms } \\
\text { Lecturer How is the Indonesian } \\
\text { Language Learning process with } \\
\text { SPADA During the Covid-19 } \\
\text { Pandemic } \\
\text { is effective, because all material can be } \\
\text { conveyed to students, without having to meet } \\
\text { face to face. }\end{array}$ \\
\hline
\end{tabular}




\begin{tabular}{|l|l|l|}
\hline $\begin{array}{l}\text { 6. Are all Indonesian language } \\
\text { learning } \\
\text { carried out with SPADA }\end{array}$ & $\begin{array}{l}\text { No, there are some materials that must be } \\
\text { conveyed directly, such as making scientific } \\
\text { essays and }\end{array}$ \\
\hline
\end{tabular}

\subsection{Online Questionnaire Results with Lecturers}

a) Learning Indonesian with SPADA is Very Effective during the Covid-19 Pandemic

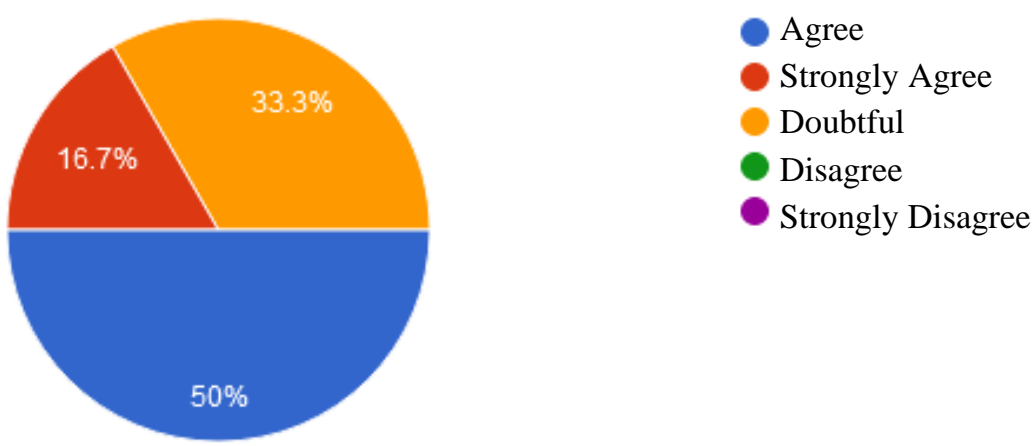

Figure a above shows that $50 \%$ of the lecturers agreed that Indonesian language learning was carried out with SPADA during the pandemic, 33.3\% of the lecturers answered doubtful, and $16.7 \%$ strongly disagreed.

b. Implementation of Indonesian Language Learning with SPAD during the Covid-19 Pandemic is Very Good

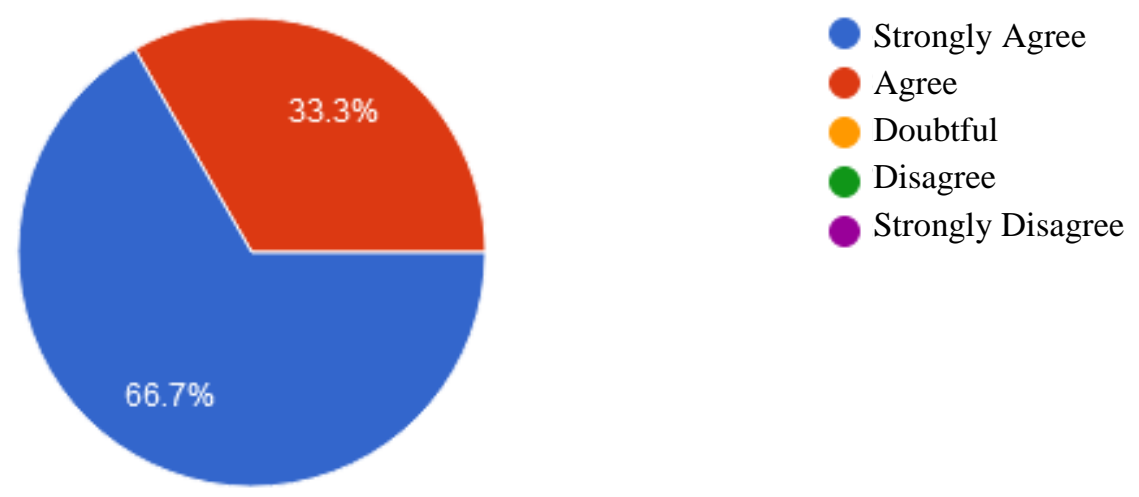

In this study, in the picture there is a very simple answer, namely $66.7 \%$ of the lecturers agreed that Indonesian language learning was carried out with SPADA during the pandemic, and only $33.3 \%$ of the lecturers strongly agreed. 
c. The Indonesian Language Learning Process with SPADA was very good during the Covid-19 Pandemic

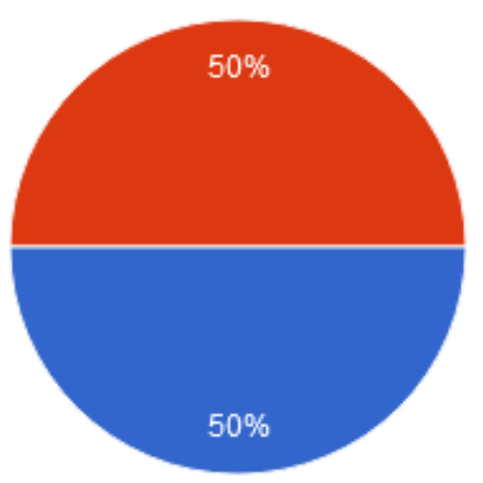

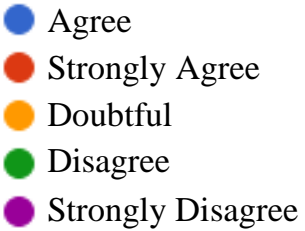

Strongly Disagree

In figure c, the lecturer answered that $50 \%$ of the Indonesian language learning process with SPADA was very well done during a pandemic and $50 \%$ of the lecturers answered strongly agree.

d. I Am Able To Use SPADA In Making Indonesian Language Learning Materials During the Covid-19 Pandemic

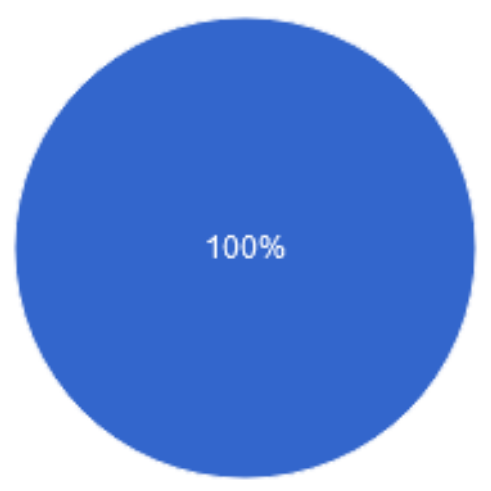

Agree

Doubtful

Disagree

Strongly Disagree

In this study, the lecturers simultaneously answered that they were $100 \%$ able to use SPADA in making Indonesian language learning materials.

e. Display on SPADA is Very Interesting and Supports Indonesian Language Learning during the Covid-19 Pandemic

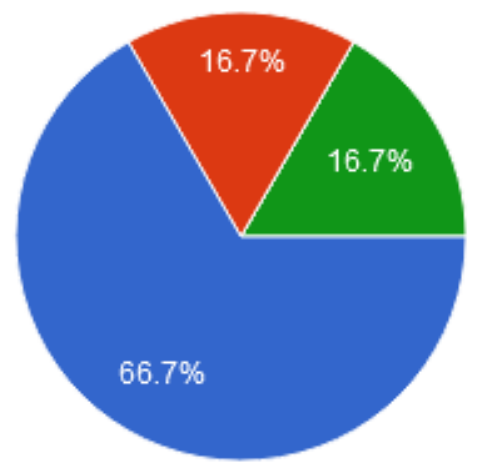

Agree

Strongly Agree

Doubtful

Disagree

Strongly Disagree 
The last picture about the appearance of SPADA is very interesting and supports learning Indonesian during a pandemic, it was found that $66.7 \%$ of the lecturers answered agree, $16.7 \%$ strongly agreed and $16.7 \%$ disagreed.

\section{Conclusion}

Based on the results of questionnaires and interviews and in accordance with the problems, several conclusions can be drawn, namely:

1. Learning Indonesian using SPADA during the Covid-19 pandemic was effective, namely, both from the results of questionnaires and interviews with lecturers and students.

2. The process of learning Indonesian using SPADA starting from planning, implementation and assessment is carried out effectively.

3. The opinion of lecturers and students to make Indonesian language learning more effective using SPADA is to add other features such as Zoom Meeting or Google Classroom.

\section{References}

Abidin, Y. (2015). Pembelajaran multiliterasi: sebuah jawaban atas tantangan pendidikan abad ke-21dalam konteks keindonesiaan. Bandung: Refika Aditama.

Afifah,D.S.N. (2012). Pendekatan Problem Posingdengan Latar Pembelajaran Kooperatif. Gamatika,

AFIFATU ROHMAWATI .Universitas Negeri Jakarta ... Vol 9 No 1 (2015): JPUD

Akhadiah,dkk. (1989). Pembinaan Kemampuan Menulis Bahasa Indonesia. Jakarta: Erlangga.

Arijani Vol 2, No 2 (2013) :https://journal.uny.ac.id/index.php/jpa/article/view/3044/2535

Arikunto, Suharsimi. 2012. Prosedur Penelitian Suatu Pendekatan Praktik. Jakarta: Rineka Cipta

Daeng nurjamal, Warta Sumirat \& Riadi Darwis. (2011).Terampil Berbahasa.Bandung : Alfabeta

Dalman. 2012. Keterampilan Menulis. Jakarta: Rajawali Pers. Daryanto. 2014. Pendekatan Pembelajaran Saintifik Kurikulum 2013. Yogyakarta: Gava Media.

Dalman. (2013). Keterampilan membaca. Jakarta: Raja Grafindo Persada

Farida Rahim. 2008. Pengajaran Membaca di Sekolah Dasar. Jakarta

Hamalik, Oemar. Psikologi Belajar dan Mengajar. Bandung: Sinar Baru Algensindo, 2001

Henry Guntur Tarigan.(2008).Menulis Sebagai Suatu Keterampilan Berbahasa.Bandung:Angkasa

https://digilib.esaunggul.ac.id/public/UEU-paper-11171-UEU-paper-11171-21_0174.pdf

https://akhmadsudrajat.files.wordpress.com/2009/04/permendiknas-no-22-tahun-2006.pdf

Ilhamsah, Catur.Rancang Bangun Sistem Informasi Akademik Berbasis Web

Indonesian Jurnal on Networking and Security (IJNS) - ijns.org IJNS Volume 2 No 2 April 2013 - ISSN: 2302-5700 63Pada Primagama Cabang Malang. Tugas Akhir. STIKOM Surabaya.2009

Jurnal Pendidikan Usia Dini, Volume 9 Nomor 1 April 2015.

Kamus Besar Bahasa Indonesia, 2007 Edisi Baru.Jakarta: Pustaka Pheonix,

Nazir, Moh. (2005). Metode Penelitian. Jakarta: Ghalia Indonesia.

Maidar G. Arsjad dan Mukti U. S., 1991. Pembinaan Kemampuan Berbicara Bahasa Indonesia. Jakarta: Erlangga. 
Miarso, Yusufhadi. Menyemai Benih Teknologi Pendidikan. Jakarta: Kencana, 2004

Moleong Lexy J. 2004, Metodologi Penelitian Kualitatif, Bandung: Remaja Rosdakarya.

Silalahi, T. et al. (2020). The Application of Cooperative Learning Model during Online Learning in the Pandemic Period. Budapest International Research and Critics Institute-Journal (BIRCI-Journal). P. 1683-1691.

Sitorus, H.V., et al (2019). The Effect of Learning Strategy and Thinking Ability on The Students' Learning Outcomes in Economics Subject of XI Social Students in Senior High School State 1 in Pematang Siantar. Budapest International Research and Critics in Linguistics and Education (BirLE) Journal. P. 451-460.

Sugiyono (2011). Metode penelitian kuntitatif kualitatif dan R\&D. Alfabeta

Sugiyono. (2014). Metode Penelitian Pendidikan Pendekatan Kuantitatif,. Kualitatif, dan R\&D. Bandung: Alfabeta.

Sugiyono. (2012). Memahami Penelitian Kualitatif'. Bandung : ALFABETA.

Satoto, Kodrat Iman. Analisis Keamanan Sistem Informasi Akademik Berbasis Web Di Fakultas Teknik Universitas Diponegoro.Artikel Ilmiah Terpublikasi.Universitas Diponegoro.2008

Pabundu Tika, 1997. Metode Penelitian Geografi. Jakarta : Pustaka Utama.

Resmini , N. dan Juanda, D. (2007). Pendidikan Bahasa dan Sastra Indonesia di Kelas Tinggi. Bandung: UPI PRESS.

Nurhadi. 2016. Teknik Membaca. Jakarta: PT Bumi Aksara.

Somadayo, S. (2011). Strategi dan Teknik Pembelajaran Membaca. Yogyakarta: Graha Ilmu

Tarigan, H. G.(2013). Berbicara sebagai suatu keterampilan berbahasa. Bandung: Angkasa

Zainurrahman. 2011. Menulis dari Teori Hingga Praktik. Bandung: Alfabeta

Supriadie, Didi dan Deni Darmawan. Komunikasi Pembelajaran. Bandung: Rosdakarya, 2012 